\title{
Winter Survival of the Soybean Rust Pathogen, Phakopsora pachyrhizi, in Florida
}

\author{
Wayne M. Jurick II, Postdoctoral Research Associate, University of Florida, Gainesville 32611; Dario F. Narvaez, \\ Postdoctoral Research Associate, University of Florida - NFREC, Quincy 32351; Meghan M. Brennan, IFAS Sta- \\ tistics, University of Florida, Gainesville; Carrie L. Harmon, Associate Director, Southern Plant Diagnostic Net- \\ work, Gainesville, FL 32611; James J. Marois, Professor of Plant Pathology, and David L. Wright, Professor of \\ Agronomy, University of Florida - NFREC, Quincy; and Philip F. Harmon, Assistant Professor of Plant Pathology, \\ University of Florida, Gainesville
}

\begin{abstract}
Jurick, W. M., II, Narvaez, D. F., Brennan, M. M., Harmon, C. L., Marois, J. J., Wright, D. L., and Harmon, P. F. 2008. Winter survival of the soybean rust pathogen, Phakopsora pachyrhizi, in Florida. Plant Dis. 92:1551-1558.

Soybean rust (SBR) survival and host availability (kudzu, Pueraria spp.) were assessed from November 2006 through April 2007 at six sites from the panhandle to southwest Florida. Micro loggers recorded both temperature and relative humidity hourly at each location. Periods of drought and cumulative hours below $0^{\circ} \mathrm{C}$ correlated with kudzu defoliation. Inoculum potential from detached kudzu leaves was evaluated in vitro under various temperature and relative humidity levels. Kudzu leaves with SBR kept at $4^{\circ} \mathrm{C}$ produced viable urediniospores with the highest germination at all moisture levels over time. Freezing temperatures $\left(-4\right.$ and $\left.-20^{\circ} \mathrm{C}\right)$ drastically reduced spore germination. However, when leaves were incubated at low $(<35 \%)$ relative humidity, inoculum potential was prolonged. Results from this study demonstrate that both temperature and relative humidity impact $P$. pachyrhizi in the field and in vitro, and that detached kudzu leaves have the potential to serve as an inoculum source in kudzu stands.
\end{abstract}

Additional keywords: infection efficiency, over wintering

Phakopsora pachyrhizi Sydow is a microcyclic rust with uredinia producing windborne urediniospores. Urediniospores require a minimum of $6 \mathrm{~h}$ of dew for infection, with optimal levels occurring between 8 and $10 \mathrm{~h}(10)$. Temperature ranges for infection and lesion formation are from 18 to $26.5^{\circ} \mathrm{C}$ and from 9 to $28^{\circ} \mathrm{C}$, respectively (12). Telia have been observed on soybean (Glycine $\max$ (L.) Merr.) and kudzu (Pueraria spp.), but their biological role is unknown (5). Other stages of the rust life cycle (aecial and pycnial) and the alternate host have not been observed (11). The fungus has a wide host range, and numerous weedy legumes can serve as overwintering hosts, the most significant in the southeastern United States being kudzu (Pueraria spp.) $(9,15)$.

Kudzu is a perennial, semi-woody, climbing leguminous vine with trifoliate leaves that is native to China and Japan.

Corresponding author: Philip F. Harmon E-mail: pfharmon@ufl.edu

* The $\boldsymbol{e}$-Xtra logo stands for "electronic extra" and indicates that Figures 2 and 3 appear in color in the online edition.

Accepted for publication 2 July 2008.

doi:10.1094/PDIS-92-11-1551

(C) 2008 The American Phytopathological Society
Several species of kudzu (P. montana, $P$. lobata, and $P$. thunbergiana) have been described. However, the number of kudzu species in the United States is unclear and is an area of ongoing research. Kudzu was originally introduced as an ornamental plant at the Philadelphia Centennial Exposition in 1876 and later was distributed by the U.S. Soil Conservation Service to prevent soil erosion. Stand expansion occurs primarily via rooting of vines at the nodes and also occurs by seed dispersal. Subterranean tubers can survive repeated herbicide treatments over multiple years $(13,14)$. Kudzu has been estimated to cover between 2 and 7 million acres in the southeastern United States and is present in 25 of the 50 states, including Hawaii $(2,3)$.

$P$. pachyrhizi now has worldwide distribution in Africa, Argentina, Australia, Bolivia, Brazil, China, Hawaii, Japan, Nigeria, Paraguay, South Africa, and Zimbabwe (1). It was first identified on soybeans in the continental United States in Baton Rouge, LA, on 10 November 2004 (16). It has been estimated that yield losses could exceed $10 \%$ in most of the United States with up to $50 \%$ yield loss in the southeastern states (17). In 2002, Yorinori et al. (18) reported that soybean rust (SBR) had cost growers in Brazil $\sim$ US $\$ 1.2$ billion-\$500 million in yield losses and $\$ 700$ million in fungicide costs.

The objectives of this study were: (i) to monitor environmental conditions (tem- perature, relative humidity, frost, low temperature, and drought) that affect the survival of $P$. pachyrhizi and kudzu in the field, (ii) to assess germination and infection capability of urediniospores from kudzu leaves obtained from the field, and (iii) to determine the impact of temperature and relative humidity on inoculum potential of detached kudzu leaves in vitro.

\section{MATERIALS AND METHODS}

Microclimate weather data collection and analysis. Six patches of kudzu infected with SBR were selected from different regions in Florida, including: two in Quincy (Panhandle; High Bridge Rd. [ 0.202 ha] and NFREC [ 0.202 ha]), two in Citra (North Central; Sunny [ 0.809 ha] and Shady [ 0.809 ha]), one in Brooksville (Central; Hickory Hill Rd. [ 0.202 ha]), and one in Fort Myers (Southwest; Koreshan State Park [ 0.101 ha]) (Fig. 1). Local temperature and relative humidity were monitored hourly using a Logtag (MicroDAQ.com, Ltd., Contoocook, NH) micro logger at each location. The Logtag manufacturer specifications for temperature accuracy are $\left(+/-0.8^{\circ} \mathrm{C}\right)$ for temperatures between $\left(-10^{\circ} \mathrm{C}\right.$ and $\left.+40^{\circ} \mathrm{C}\right)$ and $(+/-3 \%)$ for relative humidity. However, we tested these units for precision and accuracy over a 7-day period by comparing them with data collected at a Florida Automated

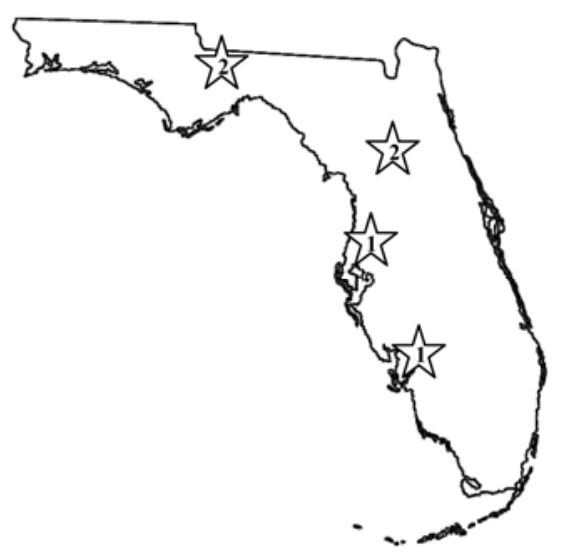

Fig. 1. Kudzu sites with soybean rust monitored during 2006-2007 winter in Florida. Stars indicate approximate locations of sites that were sampled from 8 November 2006 through 23 April 2007. Number of sites monitored per location is represented in each star. 
Weather Network (FAWN) weather station where they were located. Variation observed was slightly higher for temperature $\left(+/-1.81^{\circ} \mathrm{C}\right)$ than the manufacturer's specifications and almost identical for relative humidity (+/-3.65\%). Metal marking flags were used to attach the micro loggers to a solid surface (tree, branch, sign, etc.) at approximately $1 \mathrm{~m}$ above the soil in the kudzu canopy. Total and biweekly hours below $0^{\circ} \mathrm{C}$ and above $97 \%$ relative humidity were tabulated from hourly data for each location.

FAWN weather data collection and analysis. Total hours below $0^{\circ} \mathrm{C}$ were calculated from the minimum recorded air temperatures, and the number of hours $>97 \%$ relative humidity were tabulated from hourly averages where FAWN tower sensors recorded at $60 \mathrm{~cm}$ above the soil level for each of the six Florida counties (Gadsden, Jefferson, Marion, Hernando, Hillsborough, and Dade) from 8 November through 23 April (2005-2006 and 20062007) (FAWN, University of Florida, Institute of Food and Agricultural Sciences, Gainesville, FL; database on the internet, cited 2 October 2007). SBR incidence was obtained from the Pest Information Platform for Education and Extension (PIPE), U.S. Department of Agriculture (USDA) (database on the internet, updated 1 October 2007, cited 2 October 2007) (7). SBR incidence was determined for each kudzu site for observations following 23 April 2006/2007 (Table 1).
Kudzu sampling and urediniospore harvesting. One hundred intact kudzu leaflets were randomly sampled and sealed in a labeled plastic bag from each location approximately every 2 weeks from 8 November 2006 through 23 April 2007. Samples were primarily composed of kudzu leaflets that were attached to petioles. However, if attached leaflets were not present, then 100 leaflets from the leaf litter or suspended above the soil surface on top of kudzu vine segments were sampled randomly. The percentage of kudzu leaflets with rust was recorded as percent incidence. Leaflets obtained from the field were incubated for $12 \mathrm{~h}$ at $22^{\circ} \mathrm{C}$ followed by incubation for $12 \mathrm{~h}$ with two wet paper towels at $22^{\circ} \mathrm{C}$ and $99 \%$ relative humidity to encourage pathogen sporulation. Next, $25 \mathrm{ml}$ of Tween-treated water (TTW) (one drop of Tween 20 in $50 \mathrm{ml}$ of sterile deionized distilled water) was added to each sample bag, and the bags were sealed and shaken for $10 \mathrm{~s}$. The liquid was collected in one corner of the bag and drained into a labeled 50-ml conical tube. Typically, this procedure yielded 5 to $10 \mathrm{ml}$ of crude urediniospore suspension per bag.

Urediniospore germination on water agar. Urediniospore suspensions were vortexed for $10 \mathrm{~s}$, and $100 \mu \mathrm{l}$ of the suspension was placed on four $1.5 \%$ water agar plates. Plates were covered with aluminum foil and allowed to incubate for 12 $\mathrm{h}$ at $22^{\circ} \mathrm{C}$. Germination was assessed by randomly selecting and observing 100 urediniospores on each plate using a compound microscope at $\times 200$ (Nikon Labophot, Japan). Mean percent germination for each sample location was calculated. If plates could not be assessed after $12 \mathrm{~h}$ incubation, 10 drops of lactophenol trypan blue was added to the water agar plates to halt biological activity for subsequent assessment.

Soybean inoculations and disease assessment. Five soybean seeds of genotype 5N327RR (Mycogen, Dow Agrosciences, U.S.A.) (maturity group 3) were sown into 22.8-cm-diameter plastic pots containing Metro Mix 300 (Sun Gro Horticultural Distributors Inc., Bellevue, WA). Plants were maintained in a rust-free glass greenhouse on metal benches without shading on the Gainesville campus of the University of Florida at an average temperature of $26^{\circ} \mathrm{C}$ and an average relative humidity of $61 \%$ until needed for inoculations. Threeweek-old soybean plants (V3 growth stage) grown in a rust-free glass greenhouse were misted with TTW until runoff, and $500 \mu$ of the urediniospore suspension collected from kudzu patches was pipetted onto each one of the youngest soybean trifoliolates. All leaflets were rubbed lightly with a healthy soybean leaflet to spread the suspension. Negative controls consisted of misting with water only and rubbing uninoculated soybean leaves with healthy soybean leaves. Positive control plants were inoculated with SBR-infected leaflets (from Plexiglas greenhouse-grown

Table 1. Florida Automated Weather Network (FAWN) macroclimate data and soybean rust (SBR) incidence for kudzu from 10 sites located in six counties during winters 2005-2006 and 2006-2007 in Florida

\begin{tabular}{|c|c|c|c|c|c|c|c|c|c|}
\hline \multirow{2}{*}{\multicolumn{2}{|c|}{ FAWN tower locations }} & \multicolumn{2}{|c|}{ Kudzu site locations } & \multicolumn{3}{|c|}{ Winter 2005-2006 } & \multicolumn{3}{|c|}{ Winter 2006-2007 } \\
\hline & & \multirow{2}{*}{$\begin{array}{l}\text { Latitude, } \\
\text { longitude }\end{array}$} & \multirow[b]{2}{*}{ Sites names } & \multirow{2}{*}{$\begin{array}{l}\text { Pos/neg } \\
\text { 2006 }^{\mathrm{a}}\end{array}$} & \multirow{2}{*}{$\begin{array}{c}\text { Hours } \\
>\mathbf{9 7 \%} \mathbf{r h}^{\mathbf{b}}\end{array}$} & \multirow{2}{*}{$\begin{array}{l}\text { Hours } \\
<0^{\circ} \mathbf{C}^{\mathbf{c}}\end{array}$} & \multirow{2}{*}{$\begin{array}{c}\text { Pos/neg } \\
2007^{\mathrm{a}}\end{array}$} & \multirow{2}{*}{$\begin{array}{c}\text { Hours } \\
>\mathbf{9 7 \%} \mathbf{r h}^{\mathrm{b}}\end{array}$} & \multirow{2}{*}{$\begin{array}{l}\text { Hours } \\
<0^{\circ} \mathbf{C}^{\mathrm{c}}\end{array}$} \\
\hline Region & County & & & & & & & & \\
\hline \multirow[t]{3}{*}{ Panhandle } & Gadsden & $\begin{array}{r}30.5706 \\
-84.5720\end{array}$ & High Bridge Rd. & Pos & 526 & 157 & Pos & 363 & 132 \\
\hline & & $\begin{array}{r}30.5493 \\
-84.5973\end{array}$ & NFREC & Pos & & & Pos & & \\
\hline & Jefferson & $\begin{array}{r}30.47240 \\
-83.89046\end{array}$ & McDonalds & Pos & 210 & 164 & Pos & 94 & 132 \\
\hline \multirow[t]{3}{*}{ North Central } & Marion & $\begin{array}{r}29.4161 \\
-82.1084\end{array}$ & Citra Sunny & Pos & 591 & 68 & Pos & 712 & 29 \\
\hline & & $\begin{array}{r}29.39996 \\
-82.20516\end{array}$ & $441 / \mathrm{Cr} 25 \mathrm{a}$ & Pos & & & Pos & & \\
\hline & & $\begin{array}{r}29.4148 \\
-82.1072\end{array}$ & Citra Shady & Pos & & & Pos & & \\
\hline \multirow[t]{3}{*}{ Central } & Hernando & $\begin{array}{r}28.4793 \\
-82.2950\end{array}$ & Hickory Hill Rd. & Pos & 527 & 158 & Pos & 30 & 63 \\
\hline & & $\begin{array}{r}28.47860 \\
-82.03420\end{array}$ & Hickory Creek Ln. & Pos & & & Pos & & \\
\hline & Hillsborough & $\begin{array}{r}27.93773, \\
-82.26552\end{array}$ & Brandon Blvd. & Pos & 125 & 1 & Dest $^{d}$ & 0 & 0 \\
\hline South East & Dade & $\begin{array}{r}25.50805 \\
-80.50597\end{array}$ & TREC & Pos & 78 & 2 & Pos & 0 & 0 \\
\hline
\end{tabular}

${ }^{a}$ SBR incidence data obtained from Pest Information Platform for Education and Extension (PIPE), U.S. Department of Agriculture (USDA) (7); (database on the internet, updated 1 October 2007, cited 2 October 2007).

${ }^{\mathrm{b}}$ Hours $>97 \%$ relative humidity were compiled for each county from 8 November through 23 April for two winter seasons (2005-2006 and 2006-2007) for six Florida counties (FAWN, University of Florida, Institute of Food and Agricultural Sciences, Gainesville, FL; database on the internet, cited 2 October 2007).

${ }^{\mathrm{c}}$ Hours below $0^{\circ} \mathrm{C}$ were compiled for each county from 8 November through 23 April for two winter seasons (2005-2006 and 2006-2007) for six Florida counties (FAWN, University of Florida, Institute of Food and Agricultural Sciences, Gainesville, FL; database on the internet, cited 2 October 2007).

${ }^{\mathrm{d}}$ Destroyed due to building construction. 
plants [not shaded] with sporulating pustules that were approximately 2 weeks postinoculation) that had been misted with TTW. Plastic bags were misted with water, placed over the plants, tied off at the top, and placed on a shaded shelf in a greenhouse for $12 \mathrm{~h}$ at an average temperature of $22^{\circ} \mathrm{C}$. The following morning, the bags were removed. Plants were placed in a glass greenhouse on metal benches without shading for disease development. Soybean leaflets were assessed for SBR pustules 14 days postinoculation and recorded as percent disease incidence per trifoliolate each with three leaflets.

Assessment of inoculum potential from detached kudzu leaves. Kudzu leaflets infected with SBR were collected from
Citra, FL (Marion County) on 6 December 2006 and used for the initial and second repeat of the experiment. Kudzu leaflets infected with SBR were obtained from a site located at the intersection of Hickory Hill Road and Hickory Creek Lane in Brooksville, FL (Hernando County) on 8 April 2007 for the third repeat of the replicated experiment. Baseline spore germination and pathogenicity was evaluated by arbitrarily selecting four symptomatic kudzu leaflets and placing them in a sealed plastic bag with two wet paper towels overnight inside a plastic container. The following morning, the leaflets were removed, misted with TTW, and the resulting spore suspension was processed (as described above) to determine percent spore germination on water agar plates. The kudzu leaves were used to inoculate soybean trifoliolates (as described above, except kudzu leaves were wetted directly and rubbed onto healthy soybean leaflets). SBR-infected kudzu leaflets were rinsed two times in bulk, and each leaf was rinsed once more individually with deionized water. All leaflets were placed between paper towels to blot dry. Ten leaflets were selected randomly and viewed with a dissecting microscope to ensure lack of urediniospores on the leaf surface and within the uredinia. Leaflets were divided into groups of four and placed adaxial side up into labeled and sealed plastic bags. Levels of moisture were maintained by placing two wet paper towels with the leaflets in

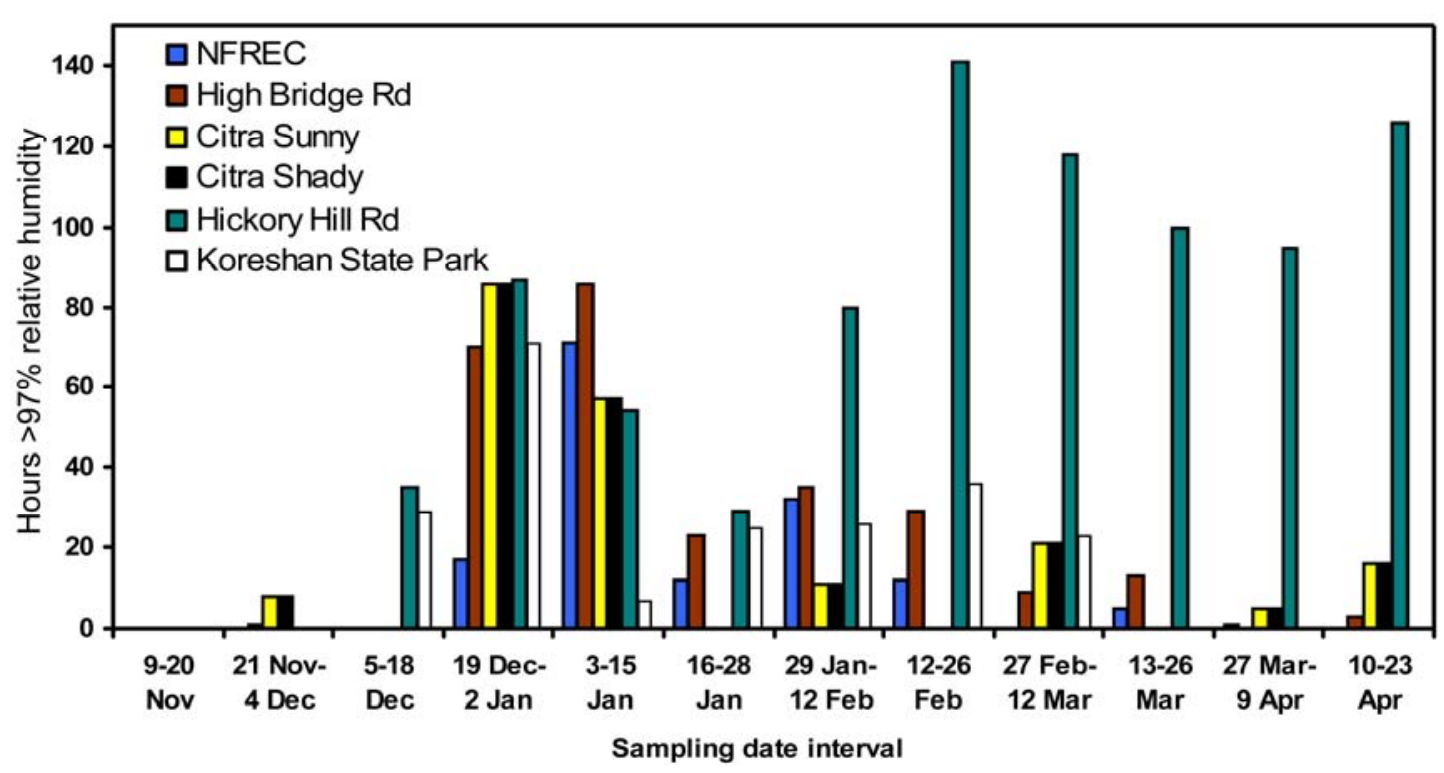

Fig. 2. Hours of relative humidity $>97 \%$ from 8 November 2006 through 23 April 2007 for kudzu located in Quincy (NFREC and High Bridge Rd.), Citra (Sunny and Shady), Brooksville (Hickory Hill Rd.), and Fort Myers (Koreshan State Park), FL.

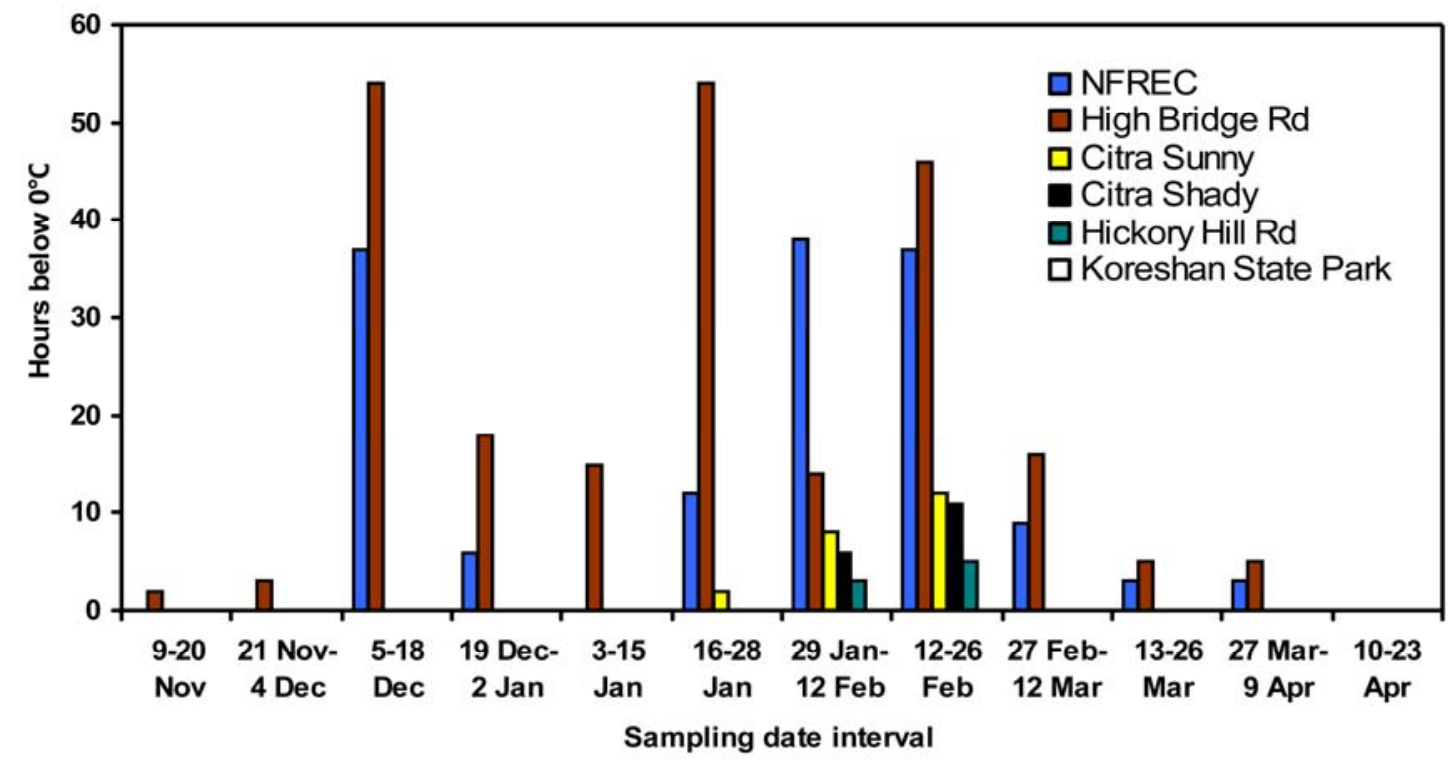

Fig. 3. Hours below $0^{\circ} \mathrm{C}$ from 8 November 2006 through 23 April 2007 for kudzu sites located in Quincy (NFREC and High Bridge Rd.), Citra (Sunny and Shady), Brooksville (Hickory Hill Rd.), and Fort Myers (Koreshan State Park), FL. 
bags assigned to the high moisture treatment (>99\% relative humidity). Calcium sulfate desiccant (100 g) and two dry paper towels were placed in bags assigned to the low moisture treatment $(<35 \%$ relative humidity). Two dry paper towels were added to no-moisture-treatment bags ( $>60 \%$ relative humidity). Bags assigned to all three moisture levels were stored in the dark at four temperatures: $22^{\circ} \mathrm{C}, 4^{\circ} \mathrm{C}$, $-4^{\circ} \mathrm{C}$, and $-20^{\circ} \mathrm{C}$. Micro loggers were placed in incubators at each temperature and in one bag at each moisture level to monitor conditions throughout the course of the study.

Statistical analyses. Data (percent spore germination) from detached kudzu leaf experiments were transformed to meet

Table 2. Microclimate data and soybean rust (SBR) incidence for kudzu sites monitored in four counties during the winter of 2006-2007 in Florida

\begin{tabular}{|c|c|c|c|c|c|}
\hline \multicolumn{2}{|c|}{ Micro logger locations } & \multicolumn{2}{|c|}{ Kudzu site locations } & \multicolumn{2}{|c|}{8 Nov 2006 to 23 Apr 2007} \\
\hline Region & County & Lat., long. & Site names & Hours $>97 \% \mathbf{r h}^{\mathrm{a}}$ & Hours $<0^{\circ} \mathbf{C}^{b}$ \\
\hline \multirow[t]{2}{*}{ Panhandle } & Gadsden & $30.5493,-84.5973$ & NFREC & 150 & 145 \\
\hline & & $30.5706,-84.5720$ & High Bridge Rd. & 269 & 232 \\
\hline \multirow[t]{2}{*}{ North Central } & Marion & $29.4161,-82.1084$ & Citra Sunny & 204 & 22 \\
\hline & & $29.4148,-82.1072$ & Citra Shady & 125 & 17 \\
\hline Central & Hernando & $28.4793,-82.2950$ & Hickory Hill Rd. & 865 & 8 \\
\hline Southwest & Lee & $26.4330,-81.8153$ & $\begin{array}{l}\text { Koreshan State } \\
\text { Park }\end{array}$ & 217 & 0 \\
\hline
\end{tabular}

${ }^{a}$ The total number of hours of relative humidity $>97 \%$ for six kudzu sites with SBR in Florida from 8 November 2006 through 23 April 2007.

${ }^{b}$ The total number of hours below $0^{\circ} \mathrm{C}$ for six kudzu sites with SBR in Florida from 8 November 2006 through 23 April 2007.

\section{A}

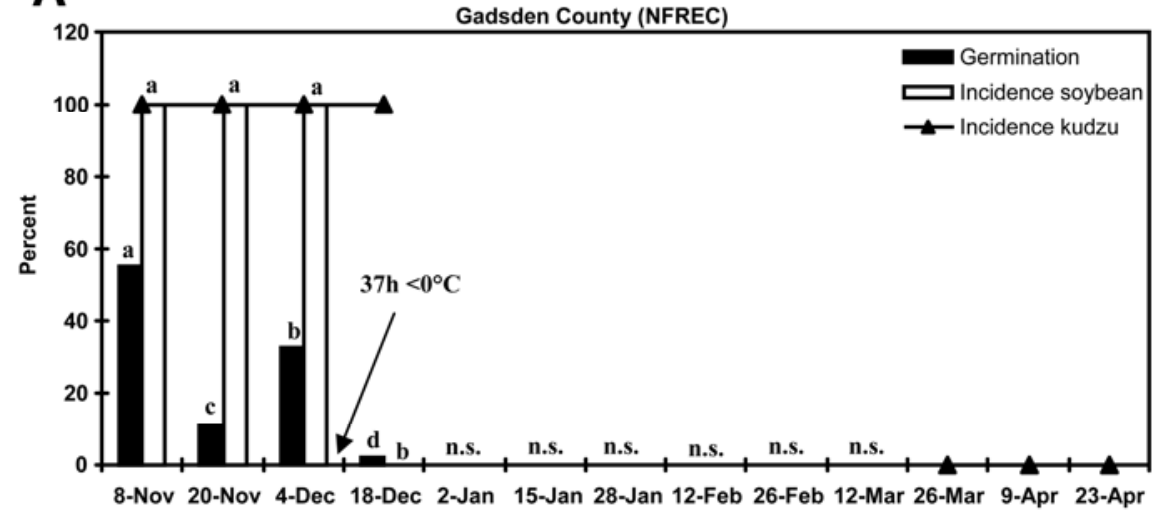

Sample date

\section{B}

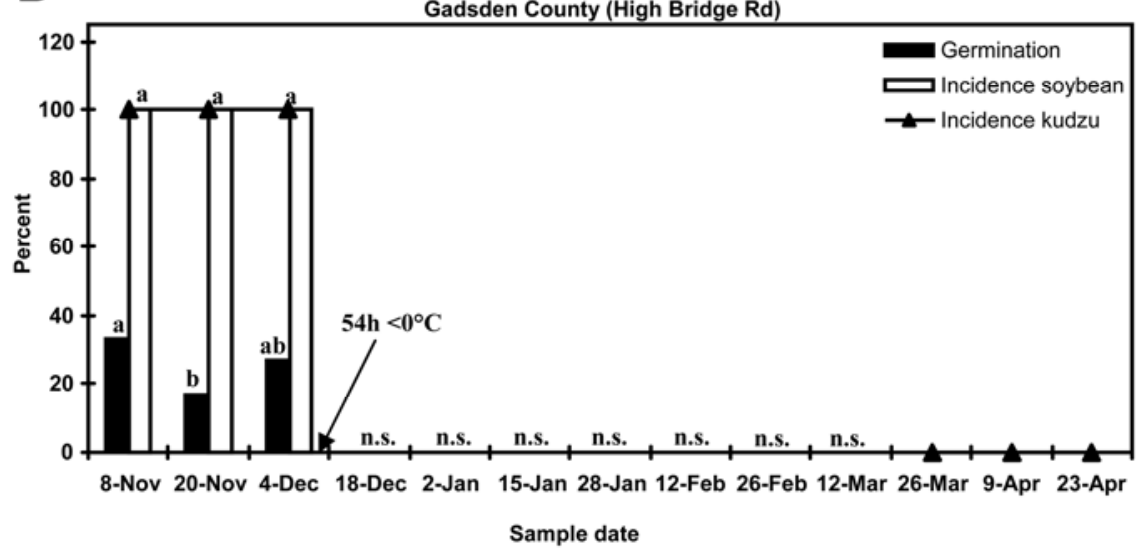

Fig. 4. Field sampling data from the panhandle region of Florida (A, NFREC, B, High Bridge Rd.) over time. Black bars represent mean percent germination and white bars represent percent incidence on soybeans from batch harvested urediniospores obtained from 100 kudzu leaflets per site. Line graph represents percent incidence of soybean rust-infected kudzu material. Bars with the same letter are not statistically significant according to Fishers protected LSD. Abbreviation "n.s." is not sampled due to lack of leaf material.
ANOVA assumptions using arcsine square root prior to statistical analysis. The transformed data were analyzed using a mixed model ANOVA (PROC MIXED) in SAS (SAS Institute Inc., Cary, NC) with repeated measures over time and block as the random effect. No significant effect due to block was determined at the $P<0.05$ level. Therefore, data from all three experiments were pooled and used to evaluate if there was a 3-factor interaction among temperature, moisture, and time at the $P<0.05$ level. Two factor interactions between temperature and moisture at each time point also were investigated at the $P<0.05$ level. Statistical analysis of the field sampling data, urediniospore germination, and soybean infection were performed using proc GLM in SAS. Means separation was carried out using Fisher's protected LSD. A chi-square test was conducted to examine the association between germination and infection using proc freq in SAS. Correlations between infection and germination were calculated using proc corr.

\section{RESULTS}

Microclimate data. The approximate locations of the six kudzu sites in Florida sampled for the presence of SBR uredinia in this study are illustrated in Figure 1. Biweekly hours of relative humidity $>97 \%$ for each site were calculated (Fig. 2). On a biweekly basis, the Hickory Hill location experienced the most hours above $97 \%$ relative humidity, with the greatest frequency occurring between 13 February 2007 and 23 April 2007. Hickory Hill also had the greatest cumulative number of hours (over a 6-month period from 8 November 2006 through 23 April 2007) of relative humidity $>97 \%$ compared with the other locations (Table 2). Biweekly hours below $0^{\circ} \mathrm{C}$ were calculated for all locations, and the greatest numbers of hours below $0{ }^{\circ} \mathrm{C}(139$ and $232 \mathrm{~h})$ were recorded at the northernmost sites (NFREC and High Bridge, respectively) (Table 2). Freezing temperatures occurred earlier in the year at the NFREC and High Bridge sites than at the other locations in the north-central and southern regions of Florida (Fig. 3). No freezing temperatures were recorded at the southernmost location at Koreshan State Park in Estero, FL.

Inoculum potential of kudzu sites with SBR. SBR incidence on kudzu leaves collected from each site (line graph), mean percent germination of urediniospores on water agar plates (black bars), and disease incidence on inoculated soybean (white bars) are shown in Figures 4 to 6 . The pathogen was detected on attached kudzu leaves from 8 November 2006 through 4 December 2006 in the northernmost locations (Fig. 4). Kudzu stands at NFREC and High Bridge were exposed to 37 and $54 \mathrm{~h}$, respectively, of below-freezing temperatures, and complete defoliation ensued. At the NFREC site, SBR-infested 
kudzu leaf litter was sampled on 18 December 2006. Germination of the urediniospores recovered from leaf litter was low (i.e., <5\%), and leaves inoculated with this spore suspension did not develop lesions. The NFREC and High Bridge Rd. sites were not sampled again until 26 March 2007 when new kudzu leaves developed.

Following $12 \mathrm{~h}$ below $0^{\circ} \mathrm{C}$ between 12 February 2007 and 26 February 2007, kudzu in the Citra Sunny and Shady sites was defoliated, and no SBR was detected after the 26 February sampling (Fig. 5). A leaf litter sample was obtained on 26 February 2007 at the Citra Sunny site, and a low level of urediniospore germination was recorded $(<5 \%)$. Kudzu leaf samples composed of green, attached leaves were obtained on 12 March 2007. However, no rust was detected at either Citra site from 12 March 2007 through 23 April 2007. Rust was detected at the Citra shady site again on 22 May and the Citra sunny site on 19 June (data not shown).

$P$. pachyrhizi was found on kudzu leaf material throughout the 6-month sampling period from 8 November 2006 through 23 April 2007 on material from the Hickory Hill Road site in Brooksville, FL (Fig. 6). There were only $5 \mathrm{~h}$ recorded where temperatures were below $0^{\circ} \mathrm{C}$ between 12 February 2007 and 26 February 2007. SBR was detected on sampled material from 20 November 2006 through 28 January 2007 at the Koreshan State Park location (Fig. 6). Multiple (12 December 2006, 15 January 2007, and 28 January 2007) leaf litter samples were obtained from this site and yielded urediniospores that germinated on water agar plates. However, when soybean plants were inoculated in the greenhouse with urediniospores from these samples, no pustules developed.

FAWN weather data for Florida winters 2005-2006 and 2006-2007. Cumulative hours of relative humidity $>97 \%$ and hours below $0^{\circ} \mathrm{C}$ were calculated for two winter seasons beginning 8 November 2005 through 23 April 2006 and 8 November 2006 through 23 April 2007 for six Florida counties. Incidence data for 10 kudzu sites that were monitored for SBR in these counties were obtained from the PIPE database. Incidence after the winter period (positive or negative) for each site was based on observations after 23 April of each year. The panhandle and northcentral regions experienced more hours below $0^{\circ} \mathrm{C}$ than the sites located in the central and southeastern regions of Florida (Table 1). Comparison of all locations between the 2 years indicated that the 2006-2007 winter was drier and warmer than the previous winter season. However, all sites were reported positive following winter conditions in 2006 and 2007 except one site located in Brandon, FL, that was destroyed due to building construction.
Inoculum potential from detached kudzu leaves with SBR in vitro. Fortyfour percent of urediniospores produced from detached kudzu leaves prior to temperature and humidity treatments germinated (average of three replicates). Surface response curves illustrate spore germination at four temperatures and three moisture levels over time (Fig. 7A to C). Below-freezing temperatures had the most consistent effect, reducing germination below our level of detection by 42 days at all moisture levels. High moisture levels (i.e., $>99 \%$ ) in storage led to reduced urediniospore germination compared with lower moisture treatments at all temperatures examined (Fig. 7A). Leaves incubated at $4^{\circ} \mathrm{C}$ produced spores with the highest germination rate on average for all temperatures over time. Desiccation and storage at low relative humidity $(<35 \%)$ reduced germination for all treatments initially (after 2 days); however, after the initial reduction, viability was prolonged in the above-freezing treatments, which had the highest germination rates after 42 days (between 15 and 25\%).
Statistical analyses of the in vitro detached kudzu leaf experiments indicate that time, moisture, and temperature are significant factors that impact urediniospore germination (Table 3). Interaction effects between temperature and moisture were apparent following incubation for 14 , 28 , and 42 days at various temperature and moisture levels. The relationship between urediniospore germination on water agar and the ability to cause infection on susceptible soybean leaves was examined using chi-square. Spore germination and infection efficiency were dependent and had a positive correlation ( 0.44 Pearson correlation coefficient, $P$ value $<0.0001)$.

\section{DISCUSSION}

The soybean rust pathogen survives in patches of kudzu in Florida through soybean-free periods. Kudzu defoliation limits host tissue available for continuation of the rust cycle and reduces the chance for rust survival in a given site. Defoliation was observed following temperatures below $0^{\circ} \mathrm{C}$ and drought in some locations (Table 2 and Fig. 1). Rust survived at levels we

A

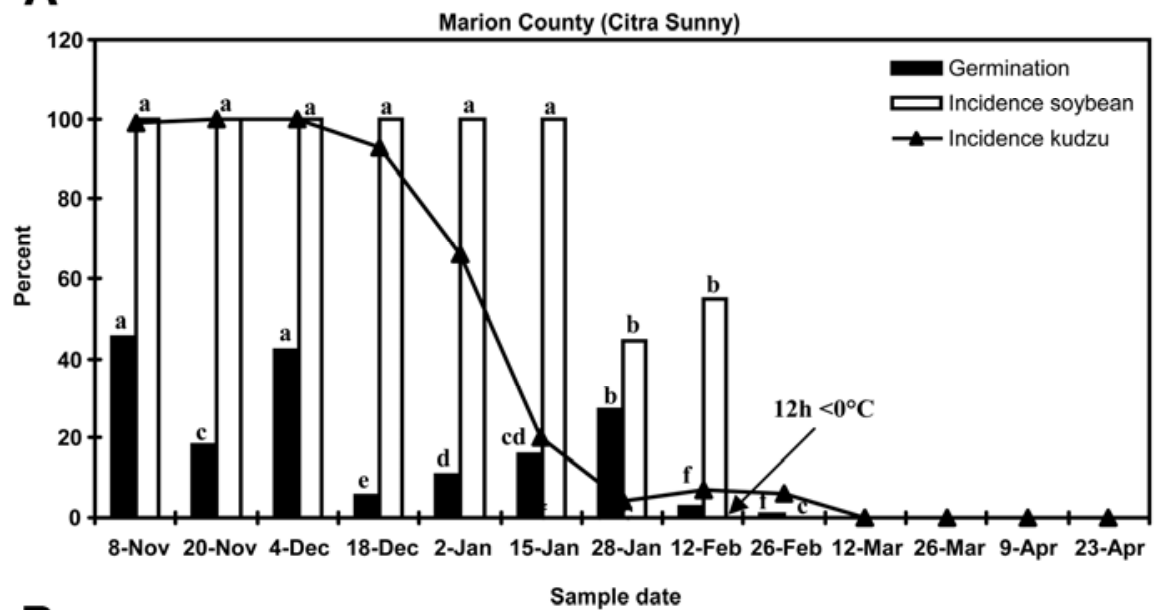

B

Sample date

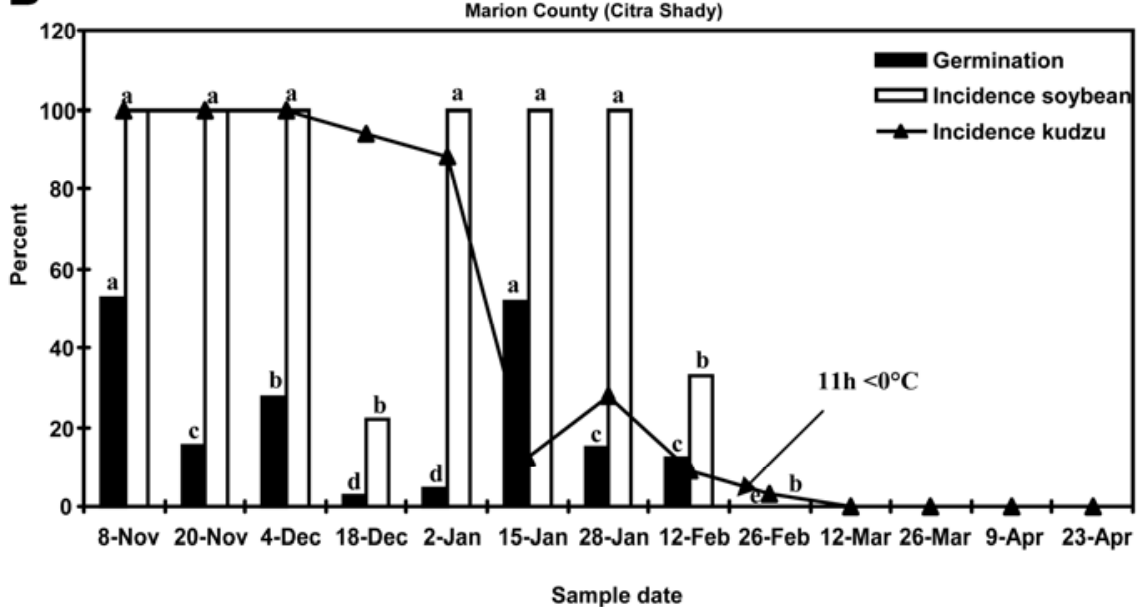

Fig. 5. Field sampling data from the north-central region of Florida (A, Citra Sunny, B, Citra Shady) over time. Black bars represent mean percent germination and white bars represent percent incidence on soybeans from batch harvested urediniospores obtained from 100 kudzu leaflets per site. Line graph represents percent incidence of soybean rust-infected kudzu material. Bars with the same letter are not statistically significant according to Fishers LSD. Abbreviation "n.s." is not sampled due to lack of leaf material. 
could detect throughout the study at the Hernando County site (Fig. 6). These results are consistent with the prediction that $P$. pachyrhizi would survive winter in Florida at locations where freezing tempera- tures occurred infrequently $(9,15)$. No rust was detected for periods of time at each of the other sites, but rust was observed in all sites in summer 2007 after conclusion of the study (Table 1). The pathogen either

A

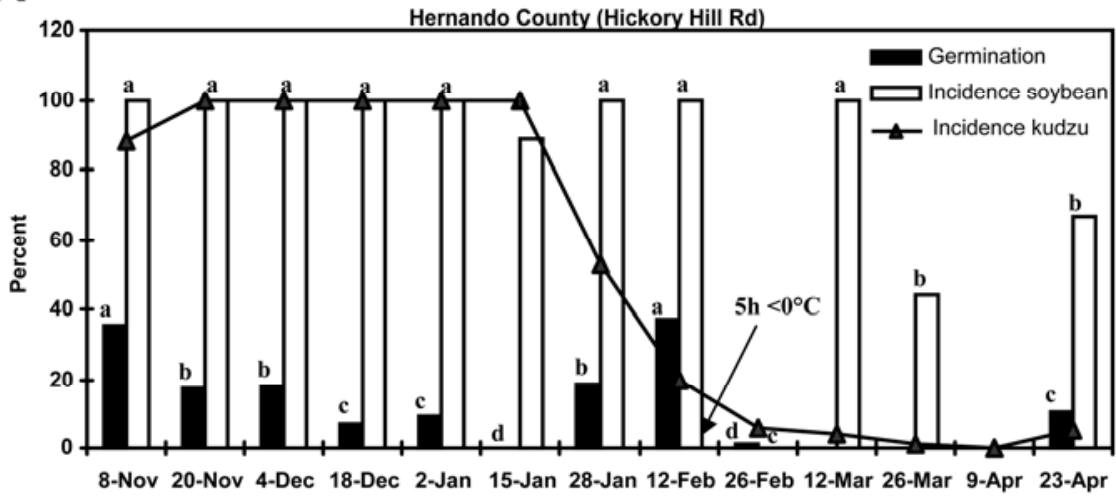

Sample date

B

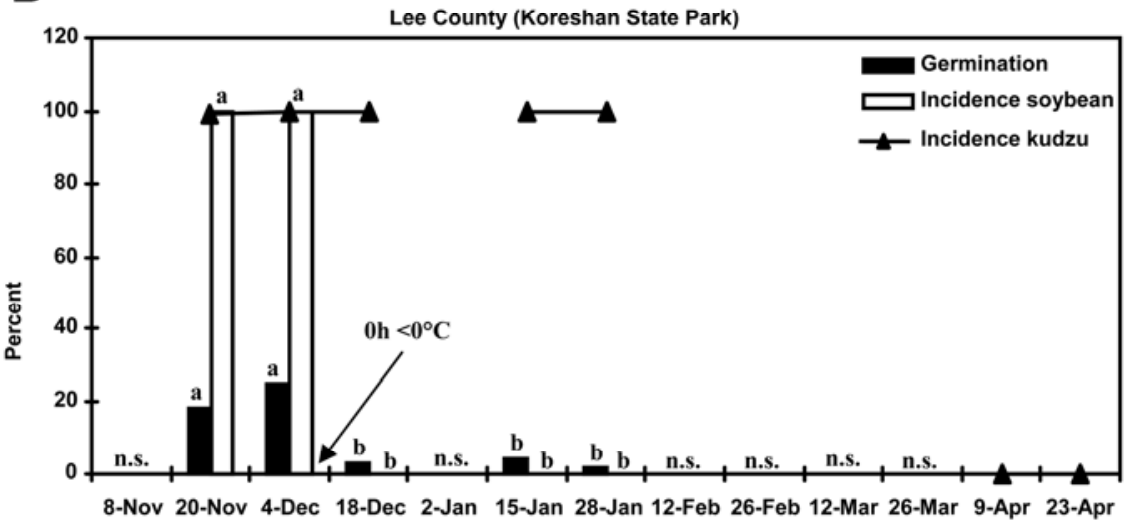

Sample date

Fig. 6. Field sampling data from the southern region of Florida (A, Hickory Hill Rd., B, Koreshan State Park) over time. Black bars represent mean percent germination and white bars represent percent incidence on soybeans from batch harvested urediniospores obtained from 100 kudzu leaflets per site. Line graph represents percent incidence of soybean rust-infected kudzu material. Bars with the same letter are not statistically significant according to Fishers LSD. Abbreviation "n.s." is not sampled due to lack of leaf material.

Table 3. Statistical analyses of inoculum potential from detached kudzu leaves in vitro

\begin{tabular}{lcccc}
\hline \multicolumn{5}{c}{ Effects over time (days) $)^{\mathbf{a}}$} \\
\hline Variable(s) & 2 & 14 & 28 & 42 \\
Temperature & $<0.001^{*}$ & $<0.001^{*}$ & $<0.001^{*}$ & $<0.001^{*}$ \\
Moisture & $<0.001^{*}$ & $<0.001^{*}$ & $<0.001^{*}$ & $<0.001^{*}$ \\
Temperature $\times$ moisture & 0.4548 & $<0.001^{*}$ & $<0.001^{*}$ & $<0.001^{*}$ \\
\hline \multicolumn{5}{c}{ Fixed effects $^{\mathbf{b}}$} \\
Variable(s) & $\mathrm{df}$ & $F$ value & $P$ value \\
Temperature & 4 & 54.6 & $<0.001^{*}$ \\
Moisture & 2 & 53.8 & $<0.001^{*}$ \\
Temperature $\times$ moisture & 8 & 3.75 & $<0.003^{*}$ \\
Time & 4 & 144 & $<0.001^{*}$ \\
Time $\times$ moisture & 6 & 9.73 & $<0.001^{*}$ \\
Time $\times$ temperature & 12 & 5.71 & $<0.001^{*}$ \\
Time $\times$ temperature $\times$ moisture & 24 & 3.79 & $<0.001^{*}$ \\
\hline
\end{tabular}

${ }^{a}$ Effects of temperature, moisture, and temperature plus moisture separated by time.

${ }^{\mathrm{b}}$ Fixed effects showing independent variables and interactions with associated $P$ values. An asterisk indicates significance at the 0.05 level.

survived at levels below our detection capability at these sites, was reestablished from inoculum produced where survival did occur, or was introduced via longdistance transport.

We investigated the possibility of pathogen survival on kudzu leaf litter by sampling the litter from sites after defoliation. A sample consisting of kudzu leaf litter was collected on 18 December 2006 from the NFREC site in Quincy, FL. The urediniospore suspension from this sample was plated on water agar and was used to inoculate soybean leaflets in the greenhouse. No disease developed on the inoculated soybean leaflets, but a small percentage of urediniospores germinated on water agar plates (Fig. 4). Additional leaf litter samples in the study from other sites had similar results. In these cases, small subsamples of the suspensions were used to inoculate a relatively few soybean leaflets per suspension and were not able to cause disease. However, a statistically significant and positive correlation between urediniospore germination on water agar and disease incidence following inoculation onto soybean was shown. Therefore, given the measured germination rate greater than zero (on water agar) for these particular spore suspensions, actual incidences should have been greater than zero as well but were likely below our level of detection. Given a larger-scale inoculation with the same suspension, low levels of disease incidence would likely be detected. The biological significance of such low levels of survival is unknown; however, the sheer scale of kudzu patches, impressive levels of infection sustained within these patches, and the observations of recurring disease in the same patches year after year seem to support the hypothesis of local survival.

Survival on detached leaves was further investigated in controlled environment incubator studies. Inoculum potential of the simulated kudzu leaf litter subjected to various temperature and relative humidity conditions was monitored over time. Urediniospore germination decreased after exposure to freezing temperatures, possibly because of ice crystal formation and cell membrane disruption. This is consistent with what has been shown for other fungal plant pathogens: Magnaporthe grisea (8), M. oryzae (6), Puccinia recondita, and $P$. graminis (4). The rapid decrease in germination observed in the $22^{\circ} \mathrm{C}$ treatment at high relative humidity was expected because leaf material deteriorated rapidly under these conditions, resulting in mycelial growth of saprophytic organisms and general rot of the leaf material. Conversely, low relative humidity $(<35 \%)$ preserved the inoculum potential of litter stored at 4 and $22^{\circ} \mathrm{C}$ (Fig. 7C). Survival on litter is most likely to occur where few hours below $0^{\circ} \mathrm{C}$ are experienced and where leaves are kept dry until new kudzu leaf material is available for infection. 
The incubator studies may help to define specific microclimates where the likelihood of pathogen survival is greatest, such as urban areas (e.g., as observed by other PIPE specialists in the southeastern states near abandoned buildings, parking lots, other concrete or asphalt surfaces) where temperatures are slightly warmer than surrounding rural areas and where residue is desiccated and slow to degrade. The in vitro studies also provide baseline information for additional studies to further investigate the limited inoculum potential of kudzu leaf litter in distinct geographic locations in the field.

Spread of SBR into major soybean producing areas of the U.S. soybean belt was hypothesized to be dependent on south-to-
A

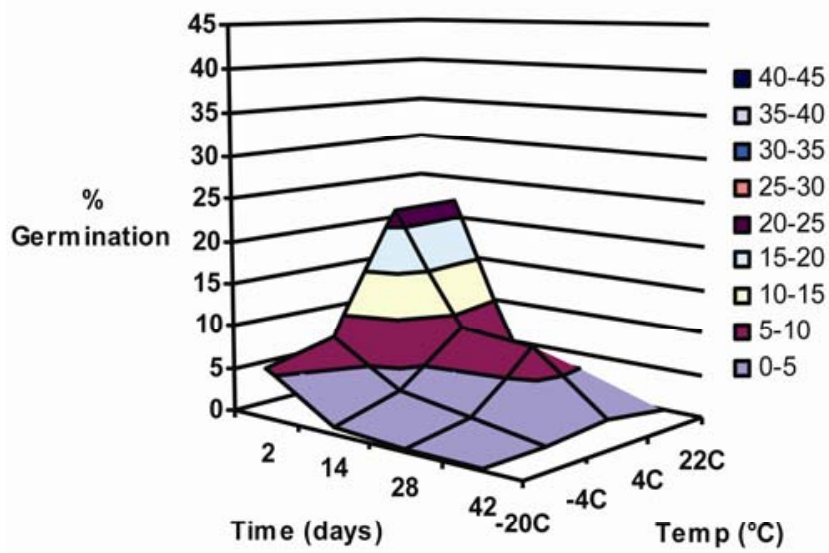

B

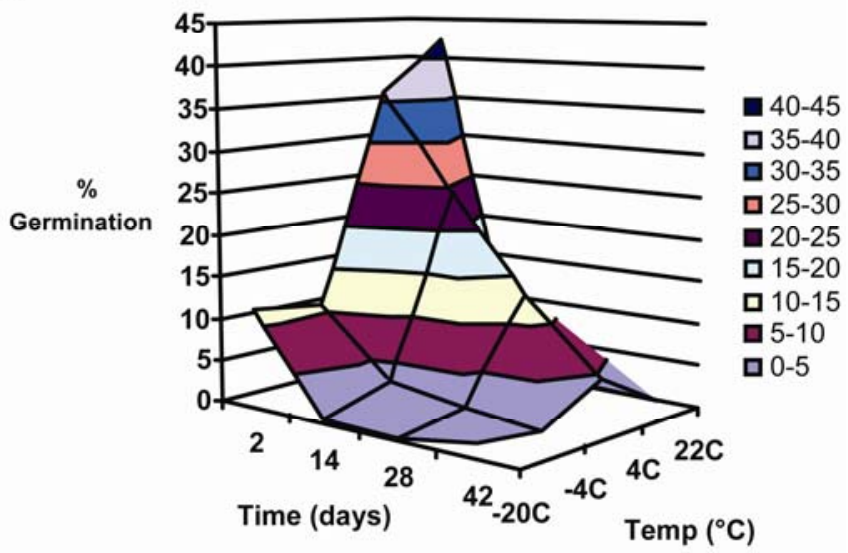

C

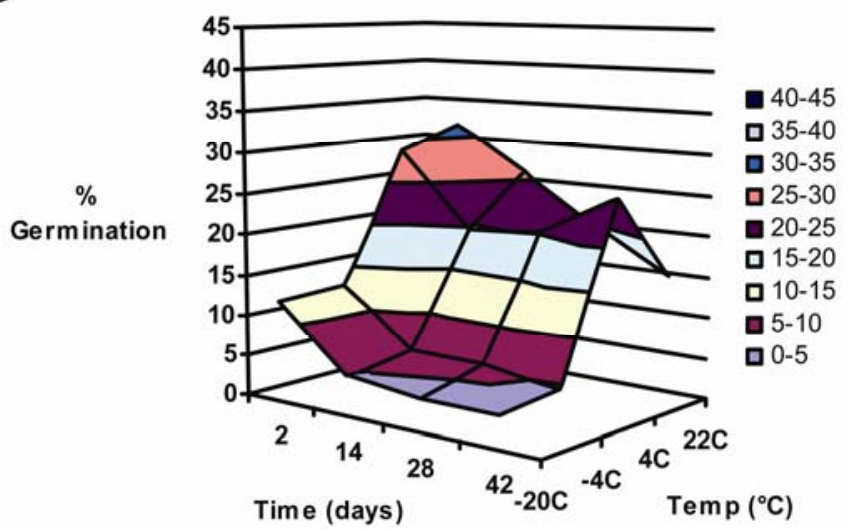

Fig. 7. Mean percent germination of urediniospores on water agar. Urediniospores were obtained from soybean rust-infected kudzu leaves that were treated at various temperatures over time at $\mathbf{A},>99 \%, \mathbf{B}$, $>60 \%$, and $\mathbf{C},<35 \%$ relative humidity levels. Initial urediniospore germination was $44 \%$ and is the mean from three replications. north dispersal of viable urediniospores (15). Therefore, understanding winter survival of $P$. pachyrhizi in Florida is vital to assess inoculum quantity and movement. We showed that $P$. pachyrhizi does survive year-round in central Florida and has the potential to produce viable urediniospores in the field well into winter, even in the panhandle of Florida. We identified that both below $0^{\circ} \mathrm{C}$ temperatures and prolonged drought can result in defoliation of kudzu. Defoliation greatly limits inoculum production in patches each year as far south as Marion County, FL. We showed that after defoliation, detached leaves can produce low levels of viable inoculum for short periods of time, but because levels of inoculum quickly fell below our limits of detection at the northern sites, we could not determine if disease observed the year following our study resulted from onsite survival of the pathogen or from ingress of inoculum. In either case, epidemics of rust in most kudzu patches north of Hernando County, FL, appear to start from low levels of initial inoculum in spring.

\section{ACKNOWLEDGMENTS}

We thank J. Stacy Strickland (UF-IFAS extension agent), Stephen M. Grigere (Koreshan State Park, environmental specialist), and G. Kelly O'Brien (NFREC, biological scientist) for collecting kudzu leaf samples from various locations during this study. We thank Jerry A. Bartz, Amanda J. Gevens, Camilla Yandoc Ables, Ivana Vico, and the anonymous reviewers who critically reviewed this manuscript. Special thanks to Carrie M. Yanke and Patty E. Hill for technical assistance during the course of this study. This work was supported by funds from the North Central Soybean Research Program.

\section{LITERATURE CITED}

1. Buitrago-Posada, M. L., and Frederick, R. D. 2005. Expressed sequence tag analysis of the soybean rust pathogen Phakopsora pachyrhizi. Fungal Genet. Biol. 42:949-962.

2. Corley, R. N., Woldeghebriel, A., and Murphy, M. R. 1997. Evaluation of the nutritive value of kudzu (Pueraria lobata) as a feed for ruminants. Anim. Feed Sci. Technol. 68:183-188.

3. Everest, J. W., Miller, J. H., Ball, D. M., and Patterson, M. G. 1991. Kudzu in Alabama. Alabama Cooperative Extension Service Circ. ANR-65. Auburn University, Auburn, AL.

4. Eversmeyer, M. G., and Kramer, C. L. 1994 Survival of Puccinia recondita and $P$. graminis urediniospores as affected by exposure to weather conditions at one meter. Phytopathology 84:332-335.

5. Harmon, C. L., Harmon, P. F., Mueller, T. A., Marois, J. J., and Hartman, G. L. 2006. First report of Phakopsora pachyrhizi telia on kudzu in the United States. Plant Dis. 90:380.

6. Harmon, P. F., and Latin, R. 2005. Winter survival of the perennial ryegrass pathogen Magnaporthe oryzae in North Central Indiana. Plant Dis. 89:412-418.

7. Isard, S. A., Russo, J. M., and DeWolf, E. D. 2006. The establishment of a national pest information platform for extension and education. Plant Management Network doi:10.1094/ PHP-2006-0915-01-RV.

8. Itoi, S., Sato, F., Yamamoto, J., Uchita, T., and Noda, C. 1979. Overwintering of Pyricularia on the living bamboo and bamboo grass leaves and pathogenicity of the rice blast fungus, $P$. 
oryzae Carava, to bamboo and bamboo grass. Ann. Phytopathol. Soc. Jpn. 43:375-385.

9. Magarey, R. D., Fowler, G. A., Borchert, D. M., Sutton, T. B., Colunga-Garcia, M., and Simpson, J. A. 2007. NAPPFAST: An internet system for the weather-based mapping of plant pathogens. Plant Dis. 91:336-345.

10. Marchetti, M. A., Melching, J. S., and Bromfield, K. R. 1976. The effects of temperature and dew period on germination and infection by urediniospores of Phakopsora pachyrhizi. Phytopathology 66:461-463.

11. Marchetti, M. A., Uecker, F. A., and Bromfield, K. R. 1975. Uredial development of Phakopsora pachyrhizi in soybeans. Phytopathology 65:822-823.
12. Melching, J. S., Dowler, W. M., Koogle, D. L., and Royer, M. H. 1989. Effects of duration, frequency, and temperature of leaf wetness periods on soybean rust. Plant Dis.73:117-122.

13. Miller, J. H. 1985. Testing herbicides for kudzu eradication on a Piedmont site. Southern J. Appl. For. 9:128-132.

14. Moorehead, D. J., and Johnson, K. D. 1996. Controlling kudzu in CRP stands. Georgia Forestry Commission Conservation Reserve Program Note 15.

15. Pivonia, S., and Yang, X. B. 2004. Assessment of the potential year-round establishment of soybean rust throughout the world. Plant Dis. 88:523-529.
16. Schneider, R. W., Hollier, C. A., Whitam, H. K., Palm, M. E., McKemy, J. M., Hernandez, J. R., Levy, L., and DeVries-Paterson, R. 2005. First report of soybean rust caused by Phakopsora pachyrhizi in the continental United States. Plant Dis. 89:774.

17. Yang, X. B., Dowler, W. M., and Tschanz, A. T. 1991. A simulation model for assessing soybean rust epidemics. J. Phytopathol. 133:187200.

18. Yorinori, J. T., Pavia, W. M., Frederick, R. D., and Fernandez, P. F. T. 2002. Ferrugem da soja (Phakopsora pachyrhzi) no Brasil e no Paraguai, nas safras 2000/01 e 2001/02. In: II Congresso Brasileiro de Soja (Foz do Iguacu, PR). Embrapa Soja, Londrina, Paraguay. 